Psychológia a patopsychológia

diefata, 53, 2019, č. 2, s. 89-102.

\title{
NEROVNÁ CESTA DO DOSPELOSTI: ŠPECIFIKÁ OBDOBIA VYNÁRAJÚCEJ SA DOSPELOSTI V KONTEXTE IDENTITY, PRÁCE A PARTNERSKÝCH VZŤAHOV
}

\author{
VERONIKA KOHÚTOVÁ - MÁRIA DĚDOVÁ \\ Katedra psychológie Filozofickej fakulty Trnavskej univerzity v Trnave
}

\begin{abstract}
NOT SO STRAIGHTWAY TO ADULTHOOD: SPECIFICS OF EMERGING ADULTHOOD PERIOD IN CONTEXT OF IDENTITY, WORK AND ROMANTIC RELATIONSHIPS
\end{abstract}

Abstract: The review study focuses on developmental period of emerging adulthood, defined by J. J. Arnett at the beginning of the $21^{\text {st }}$ century. It is a period of psychosocial moratorium between 18 and 29 years of age, characterised by specific changes in the transition from adolescence to adulthood. Identity building is becoming a main task of the period under review. It is looked at from the perspective of study, work and romantic relationships. Compared to previous generations, there has been an age shift in accepting adult social roles, and the time necessary for identity formation associated with the feelings of instability has increased. The higher demands of this period require a more in-depth exploration, understanding of its characteristics and providing help to young people on their way to adulthood.

Key words: emerging adulthood, identity, interpersonal relationships, social roles

Adolescencia je obdobím velkých zmien, končiacich dosiahnutím dospelosti. Mladý človek sa stáva dospelým, samostatným a zodpovedným za svoj život. Súčasný pokrok a zameranie sa na získavanie vzdelania a skúseností v mnohých krajinách, najmä západných, oneskoril obdobie prevzatia zodpovednosti za vlastný život. V porovnaní s minulostou väčší počet dnešných adolescentov po skončení

Prišlo 3.9.2019, V. K., FF TU, Hornopotočná 23, 91843 Trnava.

E-mail: kohutova.veronka@gmail.com

DOI: $10.4149 /$ ppd_201907 
strednej školy nezačína pracovå a osamostatňovat sa, ale pokračuje v štúdiu na vysokých školách.

Toto obdobie možností, životnú etapu experimentovania, objavovania a spoznávania sveta nazval J. J. Arnett (2000) vynárajúcou sa dospelostou.

Pozitívne myslenie u vynárajúcich sa dospelých na jednej strane a nejasná cesta $\mathrm{k}$ dosiahnutiu dospelosti na strane druhej naznačujú, že hoci obdobie vynárajúcej sa dospelosti môže byt pozitívne, zároveň prináša rôzne tažkosti a výzvy, s ktorými sa musia jednotlivci na svojej ceste $\mathrm{k}$ dospelosti vysporiadat (Arnett, 2016). Pod vplyvom rozšírených možností, nestability a neistoty nastali v životoch mladých dospelých viaceré zmeny. Do obdobia ranej dospelosti sa presunulo hladanie a vytváranie identity (Arnett, 2000), odložilo sa preberanie záväzkov a dospelých sociálnych rolí (Macek et al., 2007), oneskoril sa vstup do manželstva, rodičovstva, či pracovného života (Arnett, 2016; Arnett, Padilla-Walker, 2015; Kvapilová-Bartošová, Fučík, 2017; Šprocha, 2018). Predížením obdobia nezáväznosti a hladania, spolu s vplyvom globalizácie a zdielaním životov na sociálnych siełach (Schwartz, Tanner, Syed, 2016) sa zvýšil tlak na vynárajúcich sa dospelých.

Predkladaná prehladová štúdia sa zameriava na vybrané charakteristiky obdobia vynárajúcej sa dospelosti, ktoré poukazujú na prejavujúce sa zmeny v živote a lažkosti s nimi späté.

Zároveň poukazuje na možnosti, ako mladým ludom - vynárajúcim sa dospelým - pomôcé zvládnué náročné zmeny v kontexte tohto obdobia.

\section{Definícia pojmu vynárajúca sa dospelost}

Pojem „vynárajúca sa dospelosi““ (angl. emerging adulthood) bol prvýkrát vymedzený americkým psychológom Jeffrey J. Arnettom začiatkom 21. storočia. Vyjadruje obdobie formovania identity, prežívania nestability, činností zameraných na seba, cez nachádzanie rôznych možností $\mathrm{v}$ oblasti vzdelávania, kariéry a romantických vzlahov, s pocitom bytia medzi dvomi obdobiami, vo vekovom rozmedzí od 18 do 25/29 rokov (Arnett, Padilla-Walker, 2015). Ide o pojem, ktorý sa „zrodil“ v USA a je typický pre západné rozvinuté krajiny, v ktorých sa technický rozvoj podpísal pod zmeny spoločnosti.

V európskych krajinách sa pojem „,vynárajúca sa dospelost“" začal objavovat len niekol'ko rokov po USA. V roku 2007 bolo skúmaniu venované špeciálne číslo časopisu Journal of Adolescent Research, ktorý predstavil výsledky z viacerých krajín, medzi nimi zo Španielska, Talianska, Fínska, Nemecka a Českej republiky (Buhl, Lanz, 2007). Výskumne sa téme venovali napríklad aj v Pol'sku, Rakúsku, Nórsku či Dánsku. Hoci J. J. Arnett (2006) na základe podobných podmienok medzi USA a západnou Európou predpokladal existenciu vynárajúcej sa dospelosti ako vývinovej etapy aj v európskych krajinách, výsledky viacerých štúdií (napr. Lanz, Tangliabue, 
2007; Macek, Bejček, Vaníčková, 2007; Oleskowicz, Misztela, 2015) naznačili, že hoci sa táto životná etapa $\mathrm{v}$ európskych krajinách vyskytuje, medzi jednotlivými krajinami existujú špecifiká a rozdiely (Buhl, Lanz, 2007).

Obdobie vynárajúcej sa dospelosti je viac späté so západnými rozvinutými krajinami. Určitú podobnosị ale možno konštatovą v zmenách prechodu do dospelosti aj v krajinách strednej Európy. Podobnosti sa objavujú spolu so zmenami v ekonomike, politike, liberalizáciou noriem a postojov v smere západných krajín. Kým v západných krajinách sme svedkami zmien niekolko desatročí, v štátoch strednej Európy sa začali až po roku 1989 (porov. Oleskowicz, Miszteta, 2015; Šprocha, 2018); charakteristické sú najmä oneskoreným vstupom do manželstva a časovou diverzifikáciou preberania dospelých úloh.

Téma vynárajúcej sa dospelosti bola v Českej republike spracovaná autormi P. Macekom, J. Bejčekom a J. Vaníčkovou (2007), ktorí poskytli pomerne aktuálny obraz o vynárajúcich sa dospelých. Pri skúmaní 18-29-ročných l’udí zistili, že spíňajú mnohé vlastnosti, charakteristické pre vynárajúcich sa dospelých. Prežívajú pocity slobody, lahkomyselnosti a širokú škálu príležitostí, no zároveň pocitujú neistotu a úzkosté, prameniacu z nedostatku skúseností. Napriek plnoletosti sa necítia byẹ dospelí, nechcú robif vážne dlhodobé rozhodnutia. Uzatváranie záväzkov v oblasti interpersonálnych vztahov alebo práce odkladajú na neskôr. Spomenuté aspekty poukazujú na proces hladania identity, ktorým je obdobie vynárajúcej sa dospelosti príznačné (Macek, Bejček, Vaníčková, 2007).

Na Slovensku sa téme vynárajúcej sa dospelosti nevenuje náležitá výskumná pozornost', o čom svedčí nedostatok výskumných zistení. Záujem o výskum naznačujú zistenia o neskoršom vstupe do manželstva či narodení diełała, ktoré podobne ako v iných krajinách súvisia s obdobím vynárajúcej sa dospelosti (Šprocha, 2018; Obyvatel'stvo a migrácia, 2019). Spomínané spoločenské zmeny, ako aj výskumy okolitých krajín, zaoberajúce sa charakteristikami vynárajúcej sa dospelosti, naznačujú, že daná životná etapa a jej špecifiká by mohli bye prítomné aj v našej spoločnosti. Kultúrno-spoločenská naviazanoste vynárajúcej sa dospelosti (Arnett, 2000) však ponecháva priestor pre možné pochybnosti a vytvára potrebu výskumne overit prítomnosî charakteristík vynárajúcej sa dospelosti u mladých ludí na Slovensku.

Obdobie vynárajúcej sa dospelosti je späté s obrovskými životnými zmenami vo viacerých oblastiach života. Predložená prehladová štúdia venuje osobitnú pozornosê téme vynárajúcej sa dospelosti v kontexte identity (Whitbourne, Sneed, Sayer, 2009; Piotrowski, Brzezińska, Luyckx, 2018; Wood et al., 2018 a iné), štúdia verzus pracovnej oblasti (Schwartz et al., 2013; Mayselles, Keren, 2014; Kvapilová-Bartošová, Fučík, 2017), či partnerských a manželských vztahov (Arnett, 2016; Shulman, Connolly, 2013; Lanz, Tagliabue, 2007). 


\section{Identita v období vynárajúcej sa dospelosti}

Budovanie identity človeka sa deje v adolescencii (Erikson, 1968), no formovanie identity sa tu zd’aleka nekončí (Marcia, 1980). Naopak, rozvíja sa v čase uvedomovania si jedinečnosti osobnosti a pretrváva až do staroby. Obdobie vynárajúcej sa dospelosti významne ovplyvňuje formovanie a zmenu identity mladého človeka. Špecifikom je vytváranie a neustále pretváranie, rekonštrukcia vlastnej identity a prekonávanie následnej krízy. Hladanie odpovedí na otázky „kým som a kam smerujem" sa v tomto období objavuje častejšie a intenzívnejšie (Whitbourne, Sneed, Sayer, 2009) a stáva sa klúčovou úlohou tohto obdobia (Arnett, 2019).

Objavovanie a experimentovanie s identitou (Macek, Bejček, Vaníčková, 2007; Oleskowicz, Misztela, 2015), ktoré sa začína v adolescencii, významne pokračuje aj v období vynárajúcej sa dospelosti. Za dôvod tohto posunu považuje J. J. Arnett (2000) spoločenské zmeny, podla ktorých už nie je normou sa vo veku 20 rokov vydat, založit si rodinu, či nájsỉ stabilnú prácu. Normou sa naopak stalo hladanie identity a smerovanie v oblastiach lásky, práce a pohladu na svet (Wood et al., 2018). Očakáva sa, že mladí ludia budú v tomto veku nad’alej študovał, objavovat nové možnosti, príležitosti a hladat svoju vlastnú cestu a miesto v živote. Možnose vol’ne cestovat, študovat, spoznávat nových priatelov, kultúru, umožňuje hladanie smerovania a vytváranie identity v rámci všetkých oblastí života prostredníctvom skúseností, zážitkov, povinností, vztahov a prijímania sociálnych úloh. Obdobie budovania identity sa predížilo a je spojené s prežívaním neistoty a nestability, čo sa prejavuje zmenami $\mathrm{v}$ jednotlivých oblastiach hladania identity a v odd’alovaní preberania sociálnych úloh.

Formovanie identity súvisí s objavovaním možností a vytváraním záväzku v rôznych oblastiach života, vo vztahoch s partnerom, rodine, či vzdelaní a kariérovom smerovaní (Walsh et al., 2005). Jednotlivci postupne preberajú sociálne úlohy dospelého človeka. Hoci podla viacerých autorov (Arnett, 2000; Roupa, 2016) mladí ludia nepovažujú preberanie bežných dospelých pozícií (manžel, rodič) za významné pre definovanie seba ako dospelého, prevzatie dospelej úlohy napomáha vnímaniu seba samého ako viac dospelého (Piotrowski, Brzezińska, Luyckx, 2018). Identifikácia so sociálnou úlohou dospelého je klúčová pri formovaní identity napriek tomu, že je mladými v období vynárajúcej sa dospelosti považovaná za irelevantnú.

V minulosti mali rovesníci dnešných mladých dospelých svoju úlohu viac menej určenú očakávaniami spoločnosti. $\mathrm{V}$ súčasnosti masívnym využívaním internetu disponujú množstvom informácií o možnostiach svojho uberania sa v živote. Prechod $\mathrm{z}$ adolescencie do dospelosti sa $\mathrm{v}$ značnej miere zindividualizoval a skomplikoval. Mladí dospelí musia sami zistit, čo znamená byt dospelý, čo v živote chcú a aké budú ich dospelé úlohy (Schwartz et al., 2013). Hoci vynárajúci sa dospelí nechcú 
preberạ záväzky spojené s prebratím sociálnych rolí, seba v úlohe dospelého vidia v neskoršom období (Arnett, 2019).

\section{Štúdium verzus pracovné zaradenie mladých dospelých}

Vynárajúci sa dospelí disponujú rôznymi možnostami štúdia a príležitosłami pre zážitky, objavovanie nových miest, vyskúšanie zahraničných stáží, spoznávanie nových ludí, ktoré sú v súčasnosti vel'mi jednoduché (Schwartz et al., 2013). V období vynárajúcej sa dospelosti hladajú to, čo je pre nich najlepšie, pričom môžu kedykolvek svoj plán zmenit, pretože existuje viacero d’alších príležitostí (Schwartz, Côte, Arnett, 2005). Z množstva ponúk je náročné si vybrat, prežívat istotu v rozhodnutí a uskutočnif záväzok. V USA je počas vysokoškolského štúdia bežné v prvých rokoch niekolkokrát zmenie zameranie štúdia, čo súvisí s tým, že si konkrétny študijný odbor nevyberajú na začiatku, ale až po dvoch rokoch štúdia (Arnett, 2019). V európskom kontexte sú študenti nútení zvolit si pri výbere vysokej školy konkrétny študijný odbor a program. Hoci tak uskutočňujú určité rozhodnutie a záväzok, stále viac sa stretávame so študentami, ktorí po krátkom čase zameranie štúdia zmenia, požiadajú o prerušenie štúdia a spoznávajú iné krajiny. Stále viac sa do povedomia dostávajú príležitosti a tendencia spoznat ich potenciál.

Inštitucionálne prostredie vysokej školy vytvára priestor pre psychosociálne moratórium, v ktorom sa nad’alej formuje identita (Montgomery, Côté, 2003). Moratórium poskytuje príležitost utvárał získanú slobodu a neobmedzené možnosti, no zároveň vytvára riziko neistoty, zmätku a obáv (Schwartz et al., 2005). Dospievajúcim sa ponúka možnost využívat výhody väčšej nezávislosti, menšej kontroly, no zároveň možnosti ponechat si úlohy dospelosti ešte otvorené. Nízka miera zodpovednosti a nárokov, spojená s vysokou mierou nezávislosti a absenciou kontroly zo strany rodičov, vystavuje obdobie vynárajúcej sa dospelosti rizikovejšiemu správaniu v porovnaní s predchádzajúcim a nasledujúcim vývinovým obdobím (Rosenberg et al., 2016).

Prvé dospelé sociálne úlohy, ktoré začínajú vynárajúci sa dospelí preberat, sa dotýkajú pracovného zaradenia (Kvapilová-Bartošová, Fučík, 2017). Spomínaná nestabilita zamerania štúdia a túžba po hladaní nového a toho, čo im „,sadne,“ sa nekončí vysokoškolským štúdiom, ale pokračuje aj po prechode do práce. Svet práce, súvisiaci s prijatím povinností a zodpovednosti, častokrát menia, opúštajú, alebo sa opätovne vracajú k tréningom a získavaniu d’alších zručností (Arnett, 2000). Jedným z dôvodov „klukatého“ vstupu do kariérového života je vysoká nestabilita a rýchly vývoj pracovného prostredia (Mayselles, Keren, 2014). Navyše, pre väčšinu vynárajúcich sa dospelých práca neznamená len možnosê uživit sa, ale tiež spôsob prípravy a získania skúseností pre d’alšiu prácu a rozvoj profesijnej identity, ktorú 
si utvárajú prostredníctvom rôznych pracovných skúseností (Arnett, 2000). Experimentovanie v oblasti práce môže byê motivované snahou o nájdenie zmyslu života a spokojnosti s vlastnou kariérou (Konstam, Lehman, 2011). Hoci v minulosti boli na kariéru zameraní najmä muži, v súčasnosti sa kariéra a spokojnosê s ňou stala rovnako dôležitou pre mnoho žien, ktoré odkladajú založenie rodiny a rovnako ako muži sa venujú štúdiu a kariére.

Vynárajúci sa dospelí nachádzajú prácu na určitú dobu, získajú skúsenosti a neskôr prácu opustia či zmenia. Nie je nezvyčajné, že medzi prácou vyskúšajú stáž, ostanú istú dobu nezamestnaní (European Group for Integrated Social Research - podla Maysellesovej a Kerenovej, 2014), či sa opätovne vrátia k štúdiu (Arnett, 2019). Ako uvádza H. Berth (podla Seiffge-Krenkeovej, 2015) výrazný počet mladých ludí vo veku medzi 20-30 rokov v Nemecku uzatvára krátkodobé pracovné zmluvy, má neplatenú prax, či pracuje na nízko hodnotených pracovných miestach mimo odboru svojho vzdelania. Záväzok k práci a pracovnému miestu sa zdá byt oslabený a dôležitejšia ako samotná práca sa stáva možnosê profesionálneho rozvoja a získavanie nových zručností do času, kedy vynárajúci sa dospelí objavia svoju kariérovú cestu a vytvoria si väčší záväzok ku konkrétnej práci a kariére. Menší záväzok k práci môže súvisief aj s nižšou potrebou finančne zabezpečit rodinu, nakol'ko sú v tomto období zodpovední len za seba.

Popri štúdiu a práci tvoria relatívne vel'kú čase života mladých luudí vol’nočasové aktivity, v rámci ktorých v rozšírenom meradle hladajú svoje smerovanie, záujmy a usmerňujú svoju identitu. Podobne ako pri práci, bývaní, či vztahoch, výber vol'nočasových aktivít býva najmä na začiatku vynárajúcej sa dospelosti nestabilný, mladí svoj výber často menia (Layland, Hill, Nelson, 2018). Jednotlivci trávia volný čas objavovaním záujmov, ktoré vyhovujú ich preferenciám a umožňujú objavił nové kariérové možnosti (Murphy et al, 2010). Volnočasové aktivity vytvárajú priestor pre objavovanie vlastnej identity, či už prostredníctvom získavania nových skúseností, ako aj v spoznávaní nových ludí, budovaní priatel'stiev a romantických vztahov v kontexte záujmových aktivít. Vytvára sa potenciál pre prijatie nových záväzkov, pričom jednotlivci po vyskúšaní aktivity danú činnosỉ bud' odmietnu a hladajú d’alej, alebo prijímajú záväzky, ktoré z toho plynú. Cez prijímanie záväzkov vo forme volnočasových aktivít definujú a prezentujú okoliu osobnú identitu (Layland et al. 2018).

\section{Špecifiká vytvárania partnerských a manželských vzíahov v období vynárajúcej sa dospelosti}

Posúvanie času prevzatia dospelých sociálnych úloh možno najvýraznejšie vnímå v otázke vstupu do manželstva a založenia rodiny. Preberanie sociálnych úloh je v porovnaní s minulosiou oneskorené takmer o 10 rokov. Zatial' čo u rodičov dnešných vynárajúcich sa dospelých prichádzalo k preberaniu dospelých úloh po absolvovaní 


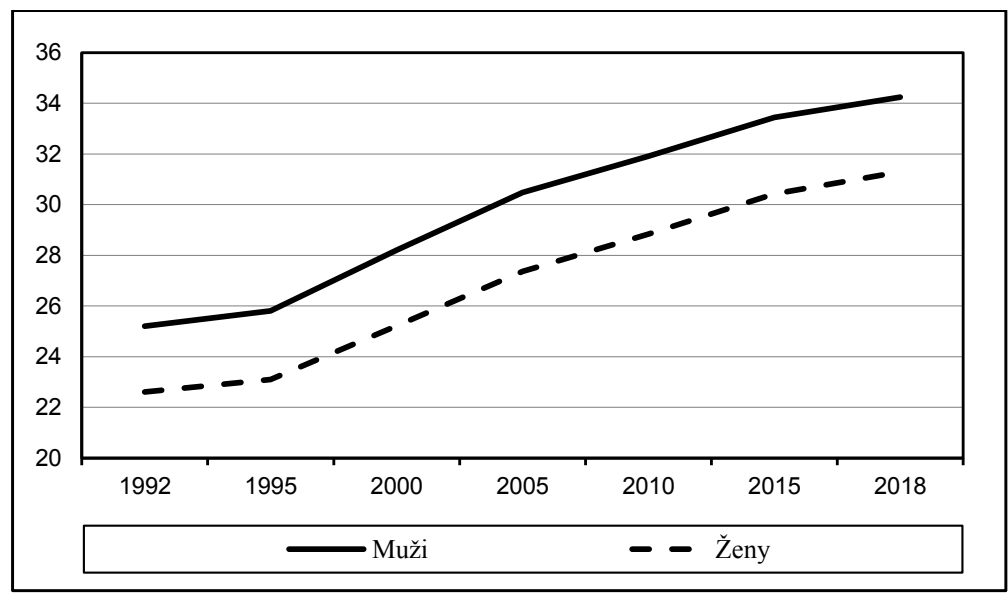

Obr. 1 Priemerný vek vstupu do manželstva na Slovensku v rokoch 1985-2018 (podla údajov Štatistického úradu SR: Obyvatelstvo a migrácia, 2019)

štúdia pomerne naraz u väčšiny vrstovníkov (Šprocha, 2018), dnešní vynárajúci sa dospelí preberajú sociálne úlohy v širšom časovom období (Kvapilová-Bartošová, Fučík, 2017). Prechod do dospelosti je komplikovanejší, nejasnejší a jednotlivé prechody nemusia byẹ nezvratné (Chaloupková, 2010).

Zvyšovanie priemerného veku uzatvárania manželstva sa vyskytuje vo viacerých rozvinutých krajinách Európy. Vyplýva z väčšej neistoty a odkladania záväzkov do budúcna s vidinou zvýšenia istoty (Šprocha, 2018). Vstup do manželstva sa naprieč Európou líši. Súvisí to s kultúrnymi a spoločenskými postojmi k bývaniu osamote alebo s partnerom bez uzatvoreného manželstva, či k významu manželstva. V Taliansku je uzatvorenie manželstva stále dôležité pre osamostatnenie sa (Lanz, Tagliabue, 2007), naopak v severských krajinách je vysoká tolerancia ku kohabitácií a priemerný vek vstupu do manželstva a prebratia príslušnej sociálnej úlohy je až okolo 30. roku života (Arnett, Padilla-Walker, 2015). Na Slovensku priemerný vek vstupu do manželstva takisto stúpa. V roku 2018 bol priemerný vek žien 31,3 roka a mužov 34,24 rokov. V Bratislave bol priemerný vek žien pri vstupe do manželstva 34,1 roka a mužov 36,65 roka (Obyvatel'stvo a migrácia, 2019). Trend stúpania priemerného veku vstupu do manželstva znázorňuje obrázok 1.

Špecifickou charakteristikou skupiny vynárajúcich sa dospelých je tiež zvýšenie priemerného veku matky pri narodení prvého diełała, ktorý dosahuje okolo 30 rokov. Muži sa k sociálnej úlohe otca dostávajú v priemere o dva roky neskôr (Arnett, Žukauskiené, Sugimura, 2014). Na Slovensku sa priemerný vek matky rovnako posunul do vyššieho veku, pričom v roku 2011 sa pohyboval v rozmedzí od 28 do 30 rokov 
(Šprocha, 2018). Dôvodom môže byt okrem absolvovania terciálneho vzdelávania a potreby etablovania sa na trhu práce tiež zmena hodnotového systému mladých ludí (Šprocha, Ďurček, 2018).

Napriek oneskorenému vstupu do manželstva a rodičovstva získavajú v živote vynárajúcich sa dospelých romantické vztahy významnejšie miesto (Lanz, Tagliabue, 2007). Postupne začínajú viac premýšlat nad typom vhodného partnera a pri hladaní si viac všímajú náznaky trvalosti vzteahu (Arnett, 2016). Svoje preferencie si ujasňujú prostredníctvom experimentovania a nezáväzných vztahov, ktoré sú v tomto období časté (Arnett, 2000).

V trvalejšom partnerskom zväzku sa nachádza menej ako polovica vynárajúcich sa dospelých (Meier, Allen, 2009), pričom druhá polovica je bud' v nezáväznom vztahu, alebo úplne bez romantického vztahu (Cohen et al., 2003). Spolu so zvyšovaním otvorenosti a liberálnosti názorov v spoločnosti sa stále viac objavujú krátkodobé vzlahy na jednu noc, ktoré podla viacerých výskumov uvádzaných S. Shulmanom a J. Connollyovou (2013) počas vysokej školy zažije aspoň raz 65-80\% študentov. Častejší je tiež výskyt vztahu, označovaného ako „priatel’ s výhodami,“" kedy ide o dlhodobejší sexuálny vztah bez záväzkov a orientácie na spoločnú budúcnost (Puentes, Knox, Zusman, 2008). Môže uspokojovat potreby mladých ludí bez potreby viazat sa. V období vynárajúcej sa dospelosti sa častejšie objavuje aj kohabitácia, ktorá ale priamo nevedie k neskoršiemu manželstvu. Mnohí, ktorí spoločne žijú, dokonca o spoločnom dlhodobom záväzku ani neuvažujú. Spoločné bývanie však býva často spojené s testovaním si možnej spoločnej budúcnosti (Shulman, Connolly, 2013). Menšia orientácia na uzatvorenie manželstva a zdôrazňovanie samotného partnerského vztahu bez potreby vytvorenia formálneho zväzku sa ukazuje byt stále viac populárna aj na Slovensku (Džambazovič, 2012).

V rôznych formách nezáväznosti romantických vztahov a testovania partnerov môžeme vnímat charakteristickú neistotu a uvedomovanie si mnohých možností a príležitostí. Podla Z. Baumana (2011) sa mladí ludia obávajú pripútat sa a vytvárat trvalejšie väzby, vd’aka ktorým by stratili možnosî opakovaného sebadefinovania a sebapresadenia, pričom túto dobu označuje ako „tekutú modernú dobu“. Vztahy v tejto dobe sú vol'né, aby ich bolo možné jednoducho ukončit, ak si to budú okolnosti vyžadovat. Príkladom môžu byt vynárajúci sa dospelí v období štúdia. Stále môžu spoznávat nové možnosti a získanie istoty správneho výberu partnera môže bye náročnejšie ako v minulosti. Vytvorenie záväzku zároveň súvisí oklieštením možností v iných oblastiach života, ako je napríklad štúdium či práca, kedy sa jednotlivec vo vztahu rozhoduje nielen na základe vlastného uváženia, ale tiež s prihliadnutím na partnera. To môže pôsobit ako prekážka v slobodnom využívaní možností a príležitostí vytvárai si identitu. Uzatvorenie záväzku si preto mladí ludia nechávajú na neskoršie obdobie, ked’ sú život a identita stabilnejšie. 


\section{Obdobie možností a neistoty v kontexte psychologického poradenstva}

Podla J. J. Arnetta (2000) je vynárajúca sa dospelosỉ obdobím možností. Životnú etapu experimentovania, objavovania a skúšania vníma optimisticky. S vyhranene pozitívnym náhladom nesúhlasí J. E. Côte (2014), podla ktorého je toto obdobie naopak náročné z dôvodu tlaku na vysokoškolské vzdelanie a nedostatku daných pravidiel a noriem, podla ktorých sa dospievajúci človek môže riadit. Nedostatok pravidiel a vedenia možno vidię v oblasti vzdelávania, práce, ako aj partnerských vztahov, čo približujeme vyššie v našom článku. Následkom toho sú si mladí ludia neistí svojimi rozhodnutiami, či už pri výbere odboru štúdia, pracovnej pozície, partnera, či pohladu na život a svoj životný štýl.

Na rozdiel od J. J. Arnetta ide podla J. E. Côta (tamže) skôr o obdobie zamýšlania sa než o objavovanie, následkom čoho je pre mladých náročné dosiahnư stabilnú identitu (Côte, 2000). Na druhej strane výsledky Arnettovho (2016) výskumu ukazujú, že vynárajúci sa dospelí sú optimistickí vo svojich pracovných ašpiráciách, pričom hladajú prácu, ktorá im prinesie radosê a zároveň určité dobro pre svet. Pozitívne myslenie u vynárajúcich sa dospelých na jednej strane a nejasná cesta $\mathrm{k}$ dosiahnutiu dospelosti na strane druhej naznačujú, že hoci obdobie vynárajúcej sa dospelosti môže bye pozitívne, zároveň prináša rôzne lažkosti a výzvy, s ktorými sa musia jednotlivci na svojej ceste $\mathrm{k}$ dospelosti vysporiadat.

Status identity, ktorý mladí dospelí dosiahnu ako splnenie hlavnej úlohy vynárajúcej sa dospelosti, súvisí so sebaúctou a emocionálnym prežívaním. Vytvorenie záväzku a stabilita identity sú späté zväčša s vyššou sebaúctou (Luyckx et al., 2008). Naopak, mladí ludia v statuse moratória mávajú nižšiu sebaúctu a zvyšuje sa u nich výskyt emocionálnych tažkostí, ktoré plynú z neistoty a neustáleho hladania samého seba (Berman, Weems, Stickle, 2006). Jednotlivci s neistou predstavou o vlastnej identite častejšie vytvárajú neharmonické vztahy, zapájajú sa do deštruktívneho správania a prežívajú viac distresu (Schwartz et al., 2009). Tieto zistenia naznačujú, že hoci predížený čas experimentovania $\mathrm{v}$ živote a hladania identity môže byt príležitostou na nájdenie toho, čo je pre jednotlivca naozaj dôležité, dlhé trvanie psychosociálneho moratória spolu s menšou kontrolou a podporou, môžu viest k zvýšeniu rizikového správania a emocionálnych tažkostí.

Predíženie času objavovania umožňuje vyskúšat jednotlivé príležitosti, no nejasná cesta môže zvyšovat pochybnosti, či je zvolené smerovanie v pracovnej a osobnej oblasti správne. Mladí ludia sú vystavení väčšiemu tlaku na nájdenie toho najlepšieho (Schwartz, Tanner, Syed, 2016). Efektívnejšie zvládnutie obdobia vynárajúcej sa dospelosti môže napomôct psychologické poradenstvo, zamerané na podporu nájdenia zvládacích stratégii pri zátažových situáciách a získanie sociálnej opory, ktorá je v tomto období potrebná, no častokrát nedostatočná (Lane, 2015). Poradcovia môžu pomôct v stratégiách hladania nových priatelov a vyhovujúcej sociálnej skupiny, ktorá 
sa prechodom na vysokú školu oslabuje alebo úplne stráca. Zároveň psychologické poradenstvo samotné môže vynárajúcim sa dospelým poskytovat formu sociálnej opory. Pre psychológov je dôležité poznat a normalizovat charakteristiky daného tranzitórneho obdobia, napríklad časté zmeny či predíženie hladania identity, ktoré sa môže zdat nevhodné, no pre toto obdobie sú prirodzené. Normalizáciou môžu ulahčit prežívanie vynárajúcich sa dospelých, ktoré zvykne byê najmä príslušníkmi starších generácií (rodičmi, pedagógmi) nepochopené. Podporou pre vynárajúcich sa dospelých môže byt tiež vytvorenie bezpečného priestoru pre uvažovanie o svojich životných možnostiach v oblasti vzdelávania, práce či partnerských vztahov. Podpora môže byê poskytnutá aj v hladaní a prijatí určitých životných hodnôt a nakoniec v rozhodnutí sa pre určitú životnú cestu. Výsledkom takto zameraného poradenstva môže byt ulahčenie prechodu do dospelosti a zlepšenie well-beingu vynárajúcich sa dospelých.

\section{Záver}

Obdobie vynárajúcej sa dospelosti prináša do života jednotlivcov optimizmus, nádej na dobrú budúcnosté, čas objavovania a experimentovania. Proces stávania sa dospelým je zároveň výzvou, ktorá pre niektorých dospievajúcich predstavuje nepredvídatel’ný, stresujúci a frustrujúci čas (Ritchie et al., 2013). Krajina pôvodu, sociálna trieda a vzdelanie súvisia s mierou, v akej obdobie vynárajúcej sa dospelosti prežívajú (Arnett, 2000, 2016). Ukazuje sa, že dospievajúci vo veku 18 - 25 rokov sa naprieč rôznymi sociálnymi triedami výrazne nelíšili v charakteristikách vynárajúcej sa dospelosti, ani v očakávaniach, aké je to byt dospelý (Arnett, 2016). Navyše zmeny, ktoré vyvolali predíženie dospievania, typické pre západnú rozvinutú kultúru, sa postupne presúvajú naprieč d’alšími krajinami a môžeme predpokladat postupné rozšírenie týchto charakteristík na stále väčšiu skupinu mladých ludí.

Definovanie novej vývinovej fázy, ktorá sa týka len špecifickej skupiny, je podla J. E. Côta (2014) zbytočné, či dokonca rizikové. Podla L. B. Hendryho a M. Kloupovej (2007) je nebezpečné postavit teóriu len na trendoch a určitých historických faktoch, pretože spoločenský vývoj v posledných 100 rokoch prešiel dramatickou zmenou, ktorá sa prejavuje v správaní a dospievaní jednotlivcov v spoločnosti. Pochopenie dospievajúcich v meniacej sa spoločnosti je späté s potrebou aktualizovat teóriu, ktorá nie je (Syed, 2015) a vytvoril odbornú podporu pre efektívnejšie a bezproblémovejšie zvládnutie tohto obdobia.

Obdobiu vynárajúcej sa dospelosti sa na Slovensku z psychologického hladiska venuje len malá pozornoste, a to aj napriek značným zmenám, ktoré sa dotýkajú vel'kej skupiny slovenských mladých ludí. Štúdiou sme priblížili špecifické zmeny v oblastiach identity, štúdia, pracovného zamerania a vytvárania partnerských vzta- 
hov, ktoré môžu prinášat tažkosti mladým ludom a zároveň môžu spôsobovat určité medzigeneračné nepochopenie rozdielnej cesty do sveta dospelosti. V daných témach nezhŕňame len poznatky zahraničných autorov, ale poukazujeme tiež na dostupné slovenské ukazovatele, ktoré naznačujú prítomnosê zmien v našich podmienkach a potrebu zvýšị záujem o prezentovanú tému.

\section{LITERATÚRA}

ARNETT, J. J. 2000. Emerging adulthood: A theory of development from the late teens through the twenties. American Psychologist, vol. 55, no. 5, p. 469-480.

ARNETT, J. J. 2006. Emerging adulthood in Europe: A response to Bynner. Journal of Youth Studies. vol. 9, no. 1, p. 111-123.

ARNETT, J. J. 2016. Does emerging adulthood theory apply across social classes? National data on a persistent question. Emerging Adulthood, vol. 4, no. 4, p. 227-235.

ARNETT, J. J. - ŽUKAUSKIENÉ, R. - SUGIMURA, K. 2014. The new life stage of emerging adulthood at ages 18-29 years: Implications for mental health. Lancet Psychiatry, vol. 1, no. 7, p. 569-576.

ARNETT, J. J. 2019. Conceptual foundations of emerging adulthood. In: MURRAY, J. L. - ARNETT, J. J. (Eds.): Emerging Adulthood and Higher Education: A New Student Development Paradigm. New York: Routledge, p. 11-24.

ARNETT, J. J. - PADILLA-WALKER, L. M. 2015. Brief report: Danish emerging adults' conceptions of adulthood. Journal of Adolescence, vol. 38, p. 39-44.

BAUMAN, Z. 2013. Tekutá láska: O křehkosti lidských pout. Praha: Academia.

BERMAN, S. L. - WEEMS, C. F. - STICKLE, T. 2006. Existential anxiety in adolescents: Prevalence, structure, association with psychological symptoms and identity development. Journal of Youth and Adolescents, vol. 35, no. 3, p. 285-292.

BUHL, H. K. - LANZ, M. 2007. Emerging adulthood in Europe. Common traits and variability across five European countries. Journal of Adolescent Research, vol. 22, no. 5, p. 439-443.

COHEN, P. - KASEN, S. - CHEN, H. - HARTMARK, C. - GORDON, K. 2003. Variations in patterns of developmental transitions in the emerging adulthood period. Developmental Psychology, vol. 39, no. 4, p. 657-669.

CÔTÉ, J. E. 2000. Arrested Adulthood: The Changing Nature of Maturity and Identity. New York: New York University Press.

CÔTÉ, J. E. 2014. The dangerous myth of emerging adulthood: An evidence-based critique of a flawed developmental theory. Applied Developmental Science, vol. 18, no. 4, p. 177-188.

DŽAMBAZOVIČ, R. 2012. Rodinné správanie v demografických dátach. Bratislava: Stimul.

ERIKSON, E. 1968. Identity: Youth and Crisis. New York: Norton.

HENDRY, L.B. - KLOEP, M. 2007. Conceptualizing emerging adulthood: Inspecting the emperor's new clothes? Child Development Perspective, vol. 1, no. 2, p. 74-79.

CHALOUPKOVÁ, H. 2010. Proměny rodinných a profesných startů. Praha: Sociologický ústav AV ČR.

KONSTAM, V. - LEHMANN, I. S. 2011. Emerging adults at work and at play: Leisure, work engagement and career indecision. Journal of Career Assessment, vol. 19, no. 2, p. 151-164.

KVAPILOVÁ-BARTOŠOVÁ, M. - FUČÍK, P. 2017. Emerging adulthood, solo living and changes in gender subjectivity. Sociológia, roč. 49, č. 3, s. 265-284.

LANE, J. A. 2015. Counseling emerging adults in transition: Practical applications of attachment and social support research. The Professional Counselor, vol. 5, no. 1, p. 30-42. 
LANZ, M. - TAGLIABUE, S. 2007. Do I really need someone in order to become an adult? Romantic relationships during emerging adulthood in Italy. Journal of Adolescent Research, vol. 22 , no. 5 , p. 531-549.

LAYLAND, E. K. - HILL, B. J. - NELSON, L. J. 2018. Freedom to explore the self: How emerging adults use leisure to develop identity. Journal of Positive Psychology, vol. 13, no. 1, p. 78-91.

LUYCKX, K. - SCHWARTZ, S. J. - GOOSSENS, L. - SOENENS, B. - BEYERS, W. 2008. Developmental typologies of identity formation and adjustment in female emerging adults: A latent class growth analysis approach. Journal of Research on Adolescence, vol. 18, no. 4, p. 595-619.

MACEK, P. - BEJČEK, J. - VANÍČKOVÁ, J. 2007. Contemporary Czech emerging adults. Generation growing up in the period of social changes. Journal of Adolescent Research, vol. 22, no. 5, p. 444-475.

MARCIA, J. E. 1980. Identity in adolescence. In: ADEISON, J. (Ed.): Handbook of Adolescence Psychology. New York: Wiley, p. 109-139.

MAYSELESS, O. - KEREN, E. 2014. Finding a meaningful life as a developmental task in emerging adulthood: The domains of love and work across cultures. Emerging Adulthood, vol. 2, no. 1, p. 63-73.

MEIER, A. - ALLEN, G. 2009. Romantic relationships from adolescence to young adulthood: Evidence from the national longitudinal study of adolescent health. The Sociological Quarterly, vol. 50, no. 2, p. 308-335.

MONTGOMERY, M. J. - CÔTÉ, J. E. 2003. College as a transition to adulthood. In: ADAMS, G. R. - BERZONSKY, M. D. (Eds.): Blackwell Handbook of Developmental Psychology. Blackwell Handbook of Adolescence. Malden: Blackwell, p. 149-172.

MURPHY, K. A. - BLUSTEIN, D. L. - BOHLIG, A. J. - PLATT, M. G. 2010. The college-to-career transition: An exploration of emerging adulthood. Journal of Counseling and Development, vol. 88, no. 2, p. 174-181.

Obyvatelstvo a migrácia. Preddefinované tabulky: Pramenné dielo - Sobáše [online]. 2019. Štatistický úrad Slovenskej republiky [cit. 5.11.2019]. Dostupné na: https://slovak.statistics.sk/ wps/portal/ext/themes/demography/population/indicators

OLESKOWICZ, A. - MISZTELA, A. 2015. How do young Poles perceive their adulthood? Journal of Adolescent Research, vol. 30, no. 6, p. 683-709.

PIOTROWSKI, K. - BRZEZIŃSKA, A. I. - LUYCKX, K. 2018. Adult roles as predictors of adult identity and identity commitment in Polish emerging adults: Psychosocial maturity as an intervening variable [online]. Current Psychology. Dostupné na: https://link.springer.com/ article/10.1007/s12144-018-9903-X

PUENTES, J. - KNOX, D. - ZUSMAN, M. E. 2008. Participants in „friends with benefits“ relationships. College Student Journal, vol. 42, no. 1, p. 176-180.

RITCHIE, R. A. - MECA, A. - MADRAZO, V. L. - SCHWARTZ, S. J. - HARDY, S. A. ZAMBOANGA, B. L. - WEISSKIRCH, R. S. - KIM, S. Y. - WHITBOURNE, S. K. - HAM, L.S. - LEE, R. M. 2013. Identity dimensions and related processes in emerging adulthood: Helpful or harmful? Journal of Clinical Psychology, vol. 69, no. 4, p. 415-432.

ROUPA, M. 2016. Čo to znamená byt dospelý podla slovenských vysokoškolských študentov? Acta Geographica Universitatis Comenianae, vol. 60, no. 1, p. 37-68.

ROSENBERG, E. R. - BURT, K. B. - FOREHAND, R. L. - PAYSNICK, A. A. 2016. Youth self-views, coping with stress, and behavioral/ emotional problems: The role of incremental self-theory. Journal of Child and Family Studies, vol. 25, no. 6, p. 1713-1723.

SEIFFGE-KRENKE, I. 2015. Experiencing the transition to adulthood in Germany: Including emerging adults of the „forgotten half “. In: ŽUKAUSKIENE, R. (Ed.): Emerging Adulthood in the European Context. London: Routledge, p. 79-93. 
SHULMAN, S. - CONNOLLY, J. 2013. The challenge of romantic relationships in emerging adulthood: Reconceptualization of the field. Emerging Adulthood. vol. 1, no. 1, p. 27-39.

SCHWARTZ, S. J. - CÔTÉ, J. E. - ARNETT, J. J. 2005. Identity and agency in emerging adulthood. Two developmental routes in the individualization process. Youth and Society, vol. 37 , no. 6 , p. 201-229.

SCHWARTZ, S. J. - DONNELLAN, M. B. - RAVERT, R. D. - LUYCKX, K. - ZAMBOANGA, B. L. 2013. Identity development, personality, and well-being in adolescence and emerging adulthood: Theory, research, and recent advances. In: LERNER, R. M. - EASTERBROOKS, M.A. - MISTRY, J. - WEINER, I. B. (Eds.): Handbook of Psychology: Developmental Psychology. New York: Wiley, p. 339-364.

SCHWARTZ, S. J. - MASON, C. A. - PANTIN, H. - SZAPOCZNIK, J. 2009. Longitudinal relationships between family functioning and identity development in Hispanic adolescents: Continuity and change. Journal of Early Adolescence, vol. 29, no. 2, p. 177-211.

SCHWARTZ, S. J. - TANNER, J. L. - SYED, M. 2016. Emerging adulthood. In: WHITBOURNE, S. K. (Ed.): The Encyclopedia of Adulthood and Aging. New York: Wiley.

SYED, M. 2015. Emerging adulthood: Developmental stage, theory or nonsense? In: ARNETT, J. J. (Ed.): The Oxford Handbook of Emerging Adulthood. Oxford: Oxford University Press, p. 11-25.

ŠPROCHA, B. 2018. Prechody do dospelosti na Slovensku v priestorovej perspektíve podla sčítania obyvatel'stva 1991 a 2011. Geographical Journal, vol. 70, no. 2, p. 117-140.

ŠPROCHA, B. - ĎURČEK, P. 2018. Odkladanie materstva na Slovensku v generačnej perspektíve. Sociológia, roč. 50, č. 5, s. 550-578.

WALSH, S. - SHULMAN, S. - FELDMAN, B. - MAURER, O. 2005. The impact of immigration on the internal processes and developmental tasks of emerging adulthood. Journal of Youth and Adolescence, vol. 34, no. 5, p. 413-426.

WHITBOURNE, S. K. - SNEED, J. R. - SAYER, A. 2009. Psychosocial development from college through midlife: A 34-year sequential study. Developmental Psychology, vol. 45, no. 5, p. 1328-1340.

WOOD, D. - CRAPNELL, T. - LAU, L. - BENNETT, A. - LOTSTEIN, D. - FERRIS, M. KUO, A. 2018. Emerging adulthood as a critical stage in the life course. In: HALFON, N. - FORREST, C. - LERNER, R. - FAUSTMAN, E. (Eds.): Handbook of Life Course Health Development. Cham: Springer, p. 123-143.

Súhrn: Prehladová štúdia sa zameriava na vývinové obdobie vynárajúca sa dospelosé, vymedzené J. J. Arnettom začiatkom 21. storočia. Ide o obdobie psychosociálneho moratória medzi 18 - 29 rokmi života, charakteristické špecifickými zmenami v prechode od adolescencie do dospelosti. Hlavnou úlohou skúmaného obdobia sa stáva budovanie identity; príspevok sa naň zameriava z pohladu štúdia, práce a partnerských vztahov. V porovnaní s predchádzajúcimi generáciami dochádza $\mathrm{k}$ vekovému posunu preberania dospelých sociálnych rol a k predíženiu času formovania identity spojeného s prežívaním nestability. Zvýšená náročnosê tohto obdobia vyžaduje jeho hlbšie skúmanie, pochopenie jeho charakteristík i poskytnutie pomoci mladým lud'om na ceste do dospelosti.

Klúčové slová: vynárajúca sa dospeloste, identita, interpersonálne vztahy, sociálne roly

Mgr. Veronika Kohútová absolvovala štúdium psychológie na Filozofickej fakulte Trnavskej univerzity, kde momentálne pokračuje v doktorandskom štúdiu v odbore 
Všeobecná a experimentálna psychológia. Venuje sa problematike dospievania adolescentov a vynárajúcich sa dospelých v kontexte meniacej sa spoločnosti.

PhDr. Mária Dědová, PhD. je psychologička, vysokoškolská učitelka, momentálne prodekanka Filozofickej fakulty Trnavskej univerzity. Absolvovala odborné vzdelávanie k riešeniu problémov šikanovania na Karlovej Univerzite v Prahe, venuje sa problematike násilia, agresie a šikanovania v školách. Zaujíma sa o axiologické otázky, zmysel života z pohladu logoterapie; je frekventantkou psychoterapeutického výcviku so zameraním na logoterapiu V. E. Frankla. 